\title{
Jótékonyság és politika. A menekülteknek nyújtott közvetlen segítség közéleti hatásai
}

\author{
Feischmidt Margit - Zakariás Ildikó ${ }^{1}$
}

\begin{abstract}
Absztrakt
A tanulmány a menekülteket támogató jótékonyság és közéleti részvétel kapcsolatát vizsgálja. A jótékony cselekvés célját, tárgyát, a cselekvés normatív legitimációját, segítettek és segítők közötti interakciók elbeszéléseit a magyarországi önkéntesekkel és civilekkel készített interjúk alapján elemezzük. Jótékonyság és közéleti részvétel dinamikus viszonyát állítjuk, amely egy kétirányú reláció következménye. A jótékonyság egyrészről lehet a cselekvést megelőző közéleti elkötelezettség következménye. Ezt nevezzük a politika jótékony cselekedetekbe való átfordításának. Másrészről a civil jótékonysági akciókban való cselekvő részvétel, a szenvedéstől való megérintettség a rászorultság okaival szembesíti a politikától magukat korábban elhatároló aktorokat is, növeli a közéletre való nyitottságukat és felelősségtudatukat. Ezt a jelenséget a jótékonyság politizálódásának nevezzük. Az említett dinamikát két szempontból értelmezzük, egyrészt a jótékonyság általános irodalma felől, amellyel kapcsolatban a jótékonyság politizálódása mellett foglalunk állást, másfelől a magyar civil társadalomnak a közélethez való viszonya szempontjából. Ez utóbbival kapcsolatban azt állítjuk, hogy a menekültekkel való szolidaritás közéleti implikációja újabb érv a magyarországi közélet fragmentált, informális és performatív müködésmódja mellett, a maga lehetőségeivel és nyilvánvaló korlátaival együtt.
\end{abstract}

\begin{abstract}
This paper addresses the relationship between charity support provided for refugees in Hungary and political participation. We analyse interpretations of intentional goals and targets of action, normative ideologies and interpretations of helper-recipient interactions in qualitative interviews carried out with volunteers and donors. We claim that there is a dynamic, two-way relationship between participating in charity and political participation. Certain political commitments may imply engagement in civic helping of refugees that is what we call charitization of politics. On the other hand, participating in charity actions and becoming emotionally involved may lead to apprehending the deeper causes of suffering, increasing public responsibilities and public awareness even of those initially refusing to address such political issues. This is what we call politicization of charity. We emphasize two major aspects of this dynamic relationship. Firstly, referring to the critical theory of charity and volunteering we emphasize the politicization of charity in this particular social context. Second, we aim to contribute to the wider discussion on the relationship between civil society and politics in Hungary. The political aspects and implications of charity support for refugees revealed in this paper resonate with more general claims stating the fragmented, informal and performative character of politics in Hungary.
\end{abstract}

\section{Bevezetés}

Tanulmányunkban² a menekülők magyarországi segítőivel készült interjúk alapján a szolidaritás civil formáival és azok közéleti hatásaival foglalkozunk. Ezzel egyfelöl a

\footnotetext{
${ }^{1}$ Mindkét szerző az MTA TK Kisebbségkutató Intézet kutatója.

${ }^{2}$ A tanulmány hátterében álló kutatómunka a MTA TK Kisebbségkutató Intézetben folyt a Társadalmi konfliktusokra adott identitáspolitikai válaszok címú Inkubátor Program keretében a Társadalomkutató Központ támogatásával. Az adatfelvétel során munkatársaink voltak: Nyiri Pál, Kovai Melinda, Kovai Cili és Kispál Hanga.
} 
jótékonyság és politika viszonyának jobb megértéséhez, másfelől a jótékonyság és civil társadalom magyarországi helyzetével kapcsolatos gondolkodáshoz szeretnénk hozzájárulni.

Európa külső és belső határainál 2015 nyarán jelentkező migrációs hullámra a szervezett felelősséghárítás (organized non-responsibility) és a biztonságosítás volt a jellemző válasz. (Pries 2017) Az érkezők számát és veszélyességét hangsúlyozó bezárkózó politikák az idegenekkel szembeni félelmekre hívták fel a figyelmet, miközben maguk is újratermelték ezt a félelmet. A politika és a média egyaránt a helyzet rendkívüliséget emelte ki, amit a migrációs válság vagy krízis fogalmi keretezés jól szemléltet. A válság azonban, ahogyan kritikus értelmezések hangsúlyozták, nemcsak a vándorlás váratlan mértékére és formáira, hanem a céltársadalmak felkészületlenségére is utal. (Rajaram 2016) Az életmentés és az azonnali gondoskodás feladatait a nagy nemzetközi humanitárius intézmények (mint amilyen a Vöröskereszt, Máltai Szeretetszolgálat, Caritas, Orvosok Határok Nélkül) nem tudták ellátni. A humanitárius krízis kezelésében Európa-szerte önkéntesek milliói játszották a meghatározó szerepet.

Németországban, ahová a legtöbben érkeztek, a menedékkérők elszállásolása és ellátása, majd a hivatalokkal való kapcsolatfelvétel, a nyelvtanulás, lakás és munkahely keresés mind a civilek részvételével valósult meg. A menekülteket segítö önkéntesek aktivitása a német civil társadalom kapacitásait, az integráció társadalmi támogatottságát a német társadalom „posztmigrációs állapotát” (postmigrantische Gesellschaft), illetve mindezek ellentmondásait egyaránt jól mutatta. (Pries 2017) Svédországban, ahol az egy före eső menedékkérők száma még Németországnál is magasabb volt, ugyancsak fontos volt a civilek, azon belül a bevándorlók korábbi nemzedékéhez tartozók mozgósító hatása és közvetítő szerepe. (Pozranovic-Frickman és Makelle 2017) Sok európai országban, közöttük Hollandiában az ellenséges politikai légkör, és a szociális támogatások megvonása megnehezítette az oda érkező menekültek helyzetét. Az állam azonban nem akadályozta, sőt sok szempontból támogatta a civilek müködését a menekültek befogadásában és ellátásban. Vagyis átengedte, mondhatjuk akár úgy, kiszervezte az ellátásukat.

Franciaországban vagy Olaszországban, ahová a menekültek már korábban is nagy számban érkeztek a tengeri úton érkezők mentése és a kitoloncolás előtt állók védelme a civil társadalom mobilizálásával történt. (Cantat 2016) Mindez annak ellenére, hogy a humanitárius kormányzás részévé vált nagy civil szervezetek (pl. Orvosok Határok Nélkül) kritikus értelmezések szerint elveszítették kapcsolatukat a társadalommal. (Ticktin 2011, Fassin 2012) A balkáni út mentén számos országban feladatmegosztás alakult ki a nemzetközi humanitárius szervezetek és a helyi civilek között, amit az állami intézmények többé vagy kevésbé passzív viselkedése kísért. Görögországban a megszorítások és gazdasági nehézségek ellenére nagy számban vettek részt önkéntesek a tengeri úton érkező menekültek mentésében és sürgősségi ellátásában, amit a kormányzat és nemzetközi szervezetek egyaránt támogatnak.

Köszönjük együttműködésüket. Az értelmezés jelentős mértékben támaszkodik azokra a beszélgetésekre, amelyeket a korábban említetteken kívül Papp Z. Attilával, Melegh Attilával és Kováts Andrással, valamint a Refugee Protection and Civil Society in Europe (MTA, 2017 május 3-4) címú konferencia társszervezőivel, Ludger Priessel, Prem Kumar Rajarammal, Zentai Violával, Celine Cantattal és résztvevőivel, továbbá a Challenging the Political Beyond and Across Borders: Possibilities and Tensions of Migrants' and Solidarity Struggles' (CEU, 2016 november 17-18) címú konferencia résztvevőivel folytattunk. Köszönet mindannyiuknak. Nem utolsó sorban köszönettel tartozunk azoknak az embereknek, akik név nélkül vállalták az interjút, és ezáltal hozzájárultak a szolidaritás és a civil társadalom magyarországi müködésének megértéséhez. 
Magyarországon 2015-ben 177 ezer regisztrált és ennél valamivel több regisztrálatlan menedékkérő haladt át, összesen több mint 400 ezer ember. (KSH 2016) A kormányzat már az év elejétől az európai szekuritizációs politika élére állt. A menekülőket kriminalizáló diskurzusokat, amelyek a migrációt a magyar és ez európai biztonságot veszélyeztető jelenségként állították be, a magyarországi média és az ellenzéki diskurzusok sem tudták érdemben ellensúlyozni. (Messing-Bernáth 2016). A segítőkészség társadalmi támogatottsága mérhető volt ugyan (Zakariás 2016), kutatások mégis azt bizonyították, hogy Magyarországon sohasem látott mértéket öltött a xenofóbia. (Sik 2016, Feischmidt 2016)

2015. júniusában érte el az ország déli határát a balkáni útvonalon érkezők tömege. A fáradtságtól és hőségtől elcsigázott emberek látványa a magyar lakosság számottevő részében is szánalmat ébresztett. Feladatuknak elsősorban a pályaudvarokra érkezők fizikai ellátását, részben az állami menekültellátó intézmények felé való irányítást gondolták. Az együttérzés egy olyan környezetben, amelyet a veszély és a stigmatizáció diskurzusai dominálnak, a konkrét cselekedeteken túlmutató állásfoglalás lehet. Hogy a menekültekkel szolidáris civileknek volt-e a konkrét humanitárius intervención túlmutató elképzelésük saját felelősségükről; és ha igen, az kire irányult, a menekülő emberekre vagy a saját társadalmukra és közéletükre, olyan kérdések, amelyekkel ilyen vagy olyan formában számos elöttünk járó kutató foglalkozott.

Vizsgálati eredményeinket hat fejezetben mutatjuk be: az elsőben a jótékonyság és politika viszonyának néhány általános kérdését tekintjük át a szakirodalom alapján, a másodikban az adatokat és a vizsgálatban alkalmazott módszereket mutatjuk be; a harmadik fejezetben a jótékony cselekvést kísérő értelmezői tevékenységet elemezzük két megközelítésből, a cselekvések célja és tárgya, valamint a cselekvést legitimáló normák és ideológiák felől; ezt követően a tanulmány negyedik részében a menekültek és segítőik közötti interakciók reflexiói kerülnek a középpontba, amelyek formatív erejét fogjuk hangsúlyozni az egyéni szintü cselekvés és a közéleti értelmezés tekintetében egyaránt. A tanulmány ötödik fejeztében a korábban bemutatott narratíva típusok együtt járásának elemzésével jótékonyság és a politika nem egymást kizáró, hanem egymást erősítő dinamikus viszonyát azonosítjuk.

A tanulmány záró fejezetében a magyar menekült-szolidaritás elbeszéléseinek tanulmányozása nyomán azt állítjuk, hogy a jótékonyság és szolidaritás gyakran a cselekvést megelőző közéleti elkötelezettség következménye. Ezt nevezzük a politika jótékony cselekedetekbe való átfordításának (charitization of politics). Másrészröl megállapítjuk, hogy a jótékony cselekvés a szenvedés és a rászorultság okaival szembesíti a segítőket, közöttük olyanokat is, akik korábban elhatárolódtak a politikától, vagyis a jótékonyság növeli a közéletre való nyitottságot és felelősségtudatot. Ezt a jelenséget a jótékonyság politizálódásának (politicization of charity) nevezzük. E kétirányú dinamikát végül két szempontból értelmezzük, egyrészt a jótékonyság irodalma felől, amellyel kapcsolatban a jótékonyság politizálódása mellett foglalunk állást, másfelől a magyar civil társadalomnak a közélethez való viszonya szempontjából. Ez utóbbival kapcsolatban azt állítjuk, hogy a menekültekkel való szolidaritás közéleti implikációja újabb érv a magyarországi közélet fragmentált, informális és performatív müködésmódja mellett, a maga lehetőségeivel és nyilvánvaló korlátaival együtt.

\section{A humanitarizmus dilemmája: politizál vagy depolitizál a másokról való gondoskodás?}

A krízishelyzetben levő embereknek nyújtandó segítséget, amely általában a rászorulók vízzel, élelemmel, gyógyszerrel és menedékkel való ellátását jelenti, jó ideje leginkább 
nemzetközi humanitárius szervezetek irányítják. A szervezeti erőforrások, csakúgy mint a morális tőke jelentős része olyan intézmények kezében van mint Nemzetközi Vöröskereszt, Orvosok Határok Nélkül, Care International, Oxfam, World Vision, Save the Children Fund, és az ENSZ humanitárius szervezetei. A müködéshez szükséges anyagi erőforrások jelentős része azonban nemzeti kormányoktól (azon belül is legfőképpen OECD országoktól) származik, ami örökös feszültség forrása, és a humanitarizmussal kapcsolatos legfőbb kritikák célpontja. A humanitarizmus akadémiai irodalma az „új humanitarizmus” fogalmával jelölte azt ez erre válaszképpen több éve formálódó jelenséget, amely a humanitárius segítségnyújtásban az önkéntesek, civil közösségek szerepét látja egyre erősebbnek (Macrae 2002) $)^{1}$.

A humanitarizmus civil és professzionális szervezetei- amint arra az újabb kritikai irodalom felhívja a figyelmet - a gondoskodást, valamint annak tárgyát, a szenvedő embert állítja a középpontba. A humanitarizmus ezáltal meghatározott politikai kérdéseket - ilyenek a nemzetközi vándorlás vagy a hajléktalanság kérdése - kisajátít bizonyos érzelmek és érzelem motiválta cselekvések számára, mint az együttérzés és gondoskodás. Ennek következtében ezek a területek kikerülnek a politika és a kormányzás felelössége alól. Ticktin a filantrópia más kritikusaival (mint Didier Fassen vagy Liissa Malkki) összhangban azt állítja, hogy azok a rendszerek, amelyek a gondoskodást és a jótékonyságot helyezik a középpontba, az egyenlőtlenségeket újratermelik és depolitizálnak (Ticktin 2011), azáltal, hogy elfedik az államok felelőtlenségének kérdését.

Nem a szenvedést és a jótékonyságot, hanem az elnyomottak politikai képviseletét és a velük való együttmüködést hangsúlyozzák a mozgalmak és a mozgalomkutatás képviselői. (Nyers and Rygiel 2012, Cantat 2016, Cantat 2017, Rajaram 2016) A mozgalom paradigmában különösen fontos a migránsok, menekültek és az őket támogató aktivisták horizontális viszonya - együttmüködése - amely viszony sok esetben hangsúlyozottan ellenpontozni igyekszik a jótékonyság segítő-segített relációjában érvényesülő paternalizmust és egyenlötlenséget. Elemzésük középpontjában politikai jogok és cselekmények állnak, hangsúlyozzák, hogy a szolidaritási mozgalmak hozzájárulnak az állampolgárság kiterjesztéséhez, illetve egy inkluzív és aktív állampolgárság megvalósításához.

A másokért viselt felelösségnek két módja van: az idegenekkel szembeni jótékony cselekedetekben érvényre jutó közvetlen felelösség, valamint az intézményes, a képviseleti rendszerre vagy mozgalmakra épülő politikai felelősség. A két típus, értelmezők egy része szerint, kizárja egymást, mert míg civilek és önkéntesek tevékenysége a szolidaritás individuális formáira korlátozódik, és ezzel egy időben fenntartja a rászorultságot eredményező struktúrákat, a politikai felelősség által motivált cselekvés a struktúrákra irányul és gyakran azok megváltoztatására törekszik. (Musick és Wilson, 2008: 18, Hustinx et al, 2010) A politikai részvétel és civil jótékonyság dichotóm felfogását helyteleníti a politikai szociológus Nina Eliasoph (2013). Elismeri, hogy a civil önkéntesek cselekvése elsődlegesen és közvetlenül valóban az egyes emberekre irányul. A segítő cselekvés azonban közvetve kollektív javak, értékek érvényességét támasztja alá, amire a cselekvést kísérö, a nyilvánosság bevonásával működő értelmezői tevékenység reflektál. Ez a reflexió a felelősségekre kérdez rá elsősorban, ami a cselekvés irányát is módosíthatja, illetve kiszélesítheti.

Más esetekben a konkrét cselekvést kísérő morális reflexióknak van kapcsolódásuk a közélethez. A görög klasszikus filozófia az eudaimonea fogalmával jelöli a jó forrásával való harmonikus viszonyt, a morális parancsnak való elégtételt kísérő boldogság érzetét, amely a jótékony cselekvéssel együtt jár. A jótékony cselekvés és a politika a gyakorlatban is 
összekapcsolódik. ${ }^{3}$ Mindezeket a kapcsolódásokat és kölcsönhatásokat viszont csak akkor találjuk meg, ha azt tartjuk szem elött, hogy maguk a cselekvők hogyan kapcsolják össze, vagy választják szét az emberekkel kapcsolatos gondoskodást (caring about people) a közélet iránti törődéssel (caring about politics). (Eliasoph, 2013)

Luc Boltanski a távoli mások szenvedésére (distant suffering) adott reakciókat vizsgálta. (Boltanski 1998) Filozófiai modellekre támaszkodva a szenvedésről való beszéd forgatókönyveit, retorikai-narratív szabályszerüségeit tárta föl. Állítása szerint a szenvedésről való nyilvános beszéd három szereplőt állíthat fókuszba: a szenvedés kiváltóját (az elkövetőt, a bünöst), az áldozatot (aki szenved) vagy az áldozat segítőjét (a jótevőt). A leleplezés és az együttérzés retorikai keretezései abban különböznek egymástól, hogy a beszélő az elkövető, vagy a jótevő szerepeit állítja-e középpontba. Az együttérzés forgatókönyve a jótevőt emeli ki, és a szenvedő és a néző érzéseinek nyilvános megfogalmazásán keresztuil mozgósít. Ezzel szemben a leleplezés forgatókönyve a szenvedés okait és felelőseit keresi, és a felháborodás és harag eszközeivel teszi lehetővé a morális cselekvést (Boltanski 1998: 77-95). A kétfajta keretezés, és bennük a kétfajta érzelmi mozgósítás tétje a politikai cselekvés: az elérzékenyülés, meghatottság, empátia által dominált értelmezések a tágabb összefüggéseket, oksági viszonyokat, így köztük a hatalmi viszonyokat, a társadalmi struktúrát nem kritizálják, ezzel szemben a leleplezés forgatókönyve kritikus, felforgató. ${ }^{4}$

A politikatudomány a jótékonyságra úgy tekint, mint ami az aktív civil társadalom része, amely a humanitarizmus professzionális szervezeteit egészíti ki tevékenységével. Az önkéntesek társadalmi rekrutációja révén egyfelől a középosztály felelősségének és azonosságnak megfogalmazásában (Hustinx, Cnaan \& Handy 2010: 15), másfelől a szolidaritás kiterjesztésében, a társadalom integrációjában tölt be fontos szerepet. A tocquevilli hagyományt követő elméleti modellek szerint a civil társadalom a privát és a nyilvános szférát, az egyéni és társadalmi cselekvéseket kapcsolja össze, méghozzá a moralitás és az érzelmek mozgósításán keresztül. E két cselekvési szint együttes megjelenése teszi lehetővé a demokratikus részvételhez és a nyilvánosság müködtetéséhez szükséges civil diszpozíciók kialakulását. (Edwards 2014) A politikatudományi megközelítések tehát ellentétben a humanitarizmus és jótékonyság fent említett, többnyire antropológiai megalapozottságú kritikai elméleteivel - a civil társadalom, és benne a jótékonyság müködését a demokratikus politikai cselekvés előfeltételének, és legfőbb szocializációs terepének látják.

A magyarországi és Magyarországra vonatkozó szakirodalom a jótékonyságot a civil társadalom részeként gondolja el. A civil társadalomra pedig úgy tekint, mint aminek a rendszerváltást megelőzően az anti-politika megszervezésében, később pedig a liberális demokrácia elveinek elterjesztésében és intézményeinek létrehozatalában volt meghatározó szerepe. (Cohen - Arato 1992, Gerő - Kopper 2013) A magyar fejlődés egy negyedszázad után újra eljutott a ,védekező társadalom fázisába”, mondja Ágh Attila egy a civilek és a politika aktuális magyarországi viszonyát elemző könyv előszavában. Ezt a viszonyt egy olyan kontextusban értelmezi, amelyet az informális intézményeknek a demokrácia

\footnotetext{
${ }^{3}$ Ezt maguk a jótékony cselekvők is érzékelik, amikor arról beszélnek, hogy ahhoz, hogy ne ez történjen, erőfeszítést kell tenniük. Ilyen a cselekvőknek az a szándéka, hogy a politikai témákat elkerüljék. Másrészről a politikailag elkötelezettek is vágynak arra, hogy a petíciókhoz és tüntetésekhez képest valóságosabbnak érzett és személyesebb cselekvéseket hajtsanak végre. A jótékony cselekvés érzelmi mozgósító ereje nagyobb, mint a politikai cselekvésé, konkrét tapasztalathoz kötődik, rövidebb távon eredménnyel jár.

${ }^{4}$ Az érzelmek segítésben játszott szerepét a segítő szakmák tudományos diskurzusai is kiemelten tárgyalják, azon belül a szociális munka szakirodalmában lásd pl. Gill 2015, Ingram 2016.
} 
válságával összefüggésben látott növekvő szerepe, a képviseleti demokrácia válságából született részvételi fordulat, és a struktúrák, intézmények helyébe lépő akciók határoznak meg. (Ágh 2016: 14) A liberális elveket valló civil társadalom meggyengülését két jelenség, a (szélső)jobboldali civil társadalom erősödése (erröl bővebben Molnár 2016, Greskovits 2017), és a „civil társadalom 2010 utáni kormányzati gyarmatosítása, domesztikálása jelzi”. A politikai tér visszafoglalása címü kötet szerzői ezzel együtt úgy látják, hogy 2010 után megsokszorozódtak a hazai aluról szerveződő civil kezdeményezések, amit egyfelől a beszűkült politikai lehetőségstruktúrával magyaráznak, másfelől a megélénkült nemzetközi mozgalmi kontextussal (Kerényi 2016). Ha mennyiségi áttörés nincsen is, a civil szféra mint „,innovatív köztér” müködik. Ebbe a folyamatba ágyazódik a menekültekkel való civil szolidaritás megszerveződése.

A TÁRKI kutatói „humanitárius csodáról” beszéltek (Bernát - Kertész - Tóth 2016), de tagadták a menekülteknek nyújtott segítség közéleti hatásait. Más kutatók a politika fogalmát kifejezetten a menekültek cselekvőképességének - a képessé tételnek - a viszonyában értelmezték. Ök úgy ítélték meg, hogy a magyar civilek többsége nem tekintett aktív ágensekként a menekültekre, ami megakadályozta őket a politikai cselekvésben. (Kallius, Monterescu, Rajaram 2016). Megint más úgy találta, hogy akik az un. menekültválságot megelőzően is részt vettek a politikai véleménynyilvánításban, a menekülteknek nyújtott segítségnek is sokkal inkább tulajdonítottak politikai jelentést. Kende (2017) szerint az önkéntes segítés és a politikai részvétel motivációi jelentős átfedésben voltak, a társadalmi változás előmozdításának vágya mindkét területen fontos; inkább az eszközök, az álláspontok kifejezésének módja különbözik egymástól, semmint azok tartalma.

Cikkünkben mi is a menekültekre irányuló önkéntes segítségnyújtás és a politika kapcsolatára kérdezünk rá. Azt akartuk megtudni, hogy a segítségnyújtás mennyiben irányul a szenvedés csökkentésére, és mennyiben övezik olyan nyilvánosan is megfogalmazott ok-okozati értelmezések, amelyek túlmutatva e szenvedések aktuális, pillanatnyi feloldásán, a társadalmi struktúra mélyebb átalakítását is célozzák. Azt vizsgáljuk ezen belül, hogy e segítő cselekvések milyen társadalmi kategóriákra és csoportokra irányulnak, milyen felelősségviszonyokat jelölnek ki, és e felelösség-viszonyokat milyen elképzelés-rendszerekbe, ideológiákba ágyazzák. Mindezeken túl a civil segítségnyújtás és politika kapcsolatának irányára is rákérdezünk. Arra, hogy e felelősségekkel kapcsolatos közéleti meggyőződések hogyan válnak a menekülteket segítő jótékonyság indokaivá; és megfordítva az oksági viszonyt, e segítő gyakorlatok és cselekvések hogyan vezetnek új tudások születéséhez, a társadalomról és a kívánatos társadalmi változásokról alkotott új elképzelésekhez.

\section{A kutatás módszere és adatai}

A kutatás adatfelvétele 2015 októbere és 2016 januárja között történt, 32 interjút készítettünk. Az interjúalanyok kiválasztása a közösségi média és a tereppel való korábbi személyes kapcsolatok segítségével, valamint a kvalitatív kutatásokban ismert hólabda módszerrel történt. Törekedtünk válaszadóink szocio-kulturális hátterének diverzitására. Az interjúkról hangfelvétel készült, amit kivonatos formában írtunk le. A minta statisztikai reprezentativitásra nem törekedett, sokkal inkább azt tartottuk szem elött, hogy a kutatás megkezdésekor ismert vagy később feltáruló társadalmi és kulturális különbségek, továbbá a müködés célja és módja tekintetében látszó diverzitás tükröződjön a mintában. Az adatok elemzése Atlasti programmal történt a megalapozott elmélet szemléletét követve elsősorban kvalitatív, kisebb részben kvantitatív elemzési szempontokat tartva szem előtt, amiért a kutatást vegyes módszerünek tekintjük. (Király, Dén-Nagy, Géring-Nagy 2014) 
Az interjúalanyok jellemzőit a következő táblázatban foglaltuk össze.

1. Táblázat: A válaszadók társadalmi-demográfiai háttere

\begin{tabular}{|c|c|c|}
\hline $\begin{array}{l}\text { Válaszadók nemi, életkor, iskolázottság és foglalkozás } \\
\text { szerint }\end{array}$ & $\mathbf{N}$ & $\%$ \\
\hline \multicolumn{3}{|l|}{ Nem } \\
\hline Férfi & 16 & 50,00 \\
\hline Nő & 16 & 50,00 \\
\hline \multicolumn{3}{|l|}{ Életkor } \\
\hline $18-35$ & 10 & 31,25 \\
\hline $36-55$ & 20 & 62,50 \\
\hline $56+$ & 2 & 6,25 \\
\hline \multicolumn{3}{|l|}{ Iskolázottság } \\
\hline Főiskolás & 1 & 3,13 \\
\hline Felsőfokú végzettség & 25 & 78,13 \\
\hline Kevesebb mint felsőfokú végzettség & 3 & 9,38 \\
\hline Hiányzó válasz & 3 & 9,38 \\
\hline \multicolumn{3}{|l|}{ Foglalkozás } \\
\hline Szociális területen vagy oktatásban & 9 & 28,13 \\
\hline Más alkalmazott & 7 & 21,88 \\
\hline Tulajdonos vagy felsővezető & 8 & 25,00 \\
\hline Önfoglalkoztató (múvész, IT) & 5 & 15,63 \\
\hline Inaktív (nyugdíjas, diák) & 2 & 6,25 \\
\hline Hiányzó válasz & 1 & 3,13 \\
\hline Total & 32 & 100,00 \\
\hline
\end{tabular}

Interjúalanyainkra a magas iskolai végzettség jellemző. Ez egy általános tendencia a civilekre és önkéntesekre vonatkozóan, és még inkább a menekültekkel való civil szolidaritás területén. A meginterjúvolt segítők foglalkozási megoszlása is fontos az értelmezés szempontjából. Jelentős részük dolgozik a tágan értelmezett szociális szektorban, mint szociális munkások, társadalomkutatók, tanárok, vagy orvosok. Második kategóriába az egyéb diplomás alkalmazottak kerültek, harmadikba a vállalat tulajdonosok és menedzserek, különösen az információs technológia és a telekommunikáció területén.

\section{A jótékony cselekvés célja és tárgya}

A jótékonyság és az önkéntesség legfontosabb jellemzője, hogy cselekvésorientált. Interjúalanyainkat az ösztönözte leginkább cselekvésre, hogy úgy gondolták, a menekülteknek kézzel fogható segítségre van szükségük. A jótékony cselekvés egyfelöl közvetlen segítségnyújtást jelentett. A cselekvés második fontos formája a segítségnyújtás megszervezésére és összehangolása volt. E kettőt azonban egy harmadik, értelmezői tevékenység kísérte, amely a segítő cselekvést jelentéssel ruházza fel. A segítő munkát 
értelmező narratívákban a segítés hat ideáltípusát tudtuk megkülönböztetni aszerint, hogy miként értelmezték a segítség célját és tárgyát. Ezek az interjús korpuszban való előfordulás és az említés gyakorisági sorrendjében a következők:

2.Táblázat. A jótékony cselekvés célja és tárgya

\begin{tabular}{|l|r|r|r|}
\hline & $\begin{array}{l}\text { Említő } \\
\text { személyek } \\
\text { száma }\end{array}$ & $\begin{array}{l}\text { A szövegkorpuszban } \\
\text { való elöfordulás } \\
\text { gyakorisága }\end{array}$ & $\begin{array}{l}\text { A szövegkorpuszban } \\
\text { való elöfordulás } \\
\text { százalékban }\end{array}$ \\
\hline $\begin{array}{l}\text { Menekültekre irányuló: humanitárius } \\
\text { katasztrófa elhárítása }\end{array}$ & 23 & 54 & 23,5 \\
\hline $\begin{array}{l}\text { Segítőkre irányuló: érzelmi vagy morális } \\
\text { nyereség }\end{array}$ & 19 & 49 & 21,3 \\
\hline $\begin{array}{l}\text { A magyar lakosságra irányuló: az } \\
\text { önkéntesség megerősítése a magyar } \\
\text { társadalomban }\end{array}$ & 19 & 60 & \\
\hline $\begin{array}{l}\text { A magyar lakosságra irányuló: } \\
\text { közvélemény alakítása, a társadalmi } \\
\text { szolidaritás kiterjesztése }\end{array}$ & 15 & & 26,1 \\
\hline $\begin{array}{l}\text { Pártpolitikai aktorokra irányuló: ellenzéki } \\
\text { magatartás, lázadás }\end{array}$ & 11 & 28 & 12,2 \\
\hline Menekültekre irányuló: politikai elismerés & 7 & 19 & 8,3 \\
\hline Más & 2 & 230 & 7,8 \\
\hline Összesen & & & \\
\hline
\end{tabular}

A legtöbben úgy értelmezték, hogy a cél a humanitárius katasztrófa elhárítása volt (32 interjúalanyból 23 beszélt erről), aminek módját a segítők gondolták meghatározni. Az, hogy a segítés módját a segítetteknek kellene meghatározniuk, vagyis a segítésnek egy elismerési gesztussal való összekapcsolása már sokkal ritkábban történt meg. Vagyis úgy a típusok diverzitása, mind azok előfordulási gyakorisága arra figyelmeztet, hogy miközben a cselekvés természetesen elsődlegesen a menekültekre irányult, az utólagos értelmezésekben, amit interjúinkkal rögzíteni tudtunk, a segítőkre és az ő környezetükre irányuló reflexió lett meghatározóbb. A menekültsegítés apropójaként végzett reflexió elsősorban az önkéntes és jótékony cselekvésnek a magyar társadalomban kívánatos voltára, az önkéntesség révén megvalósuló véleményalakításra, politikai álláspont kifejezésre és a véleményközösségnek cselekvésközösséggé való átalakítására irányult.

Elöttünk járó kutatók részletes leírását adták már annak, hogy kik voltak, milyen munkát végeztek, és hogyan szerveződtek meg a menekülteket segítő magyarországi civilek. Ezen a ponton a segítő cselekvés értelmezései kerülnek előtérbe. A magyarországi segítők precedensek ismeretének hiányában és a nem kis részben a média és a politika hatására a helyzet rendkívüli és krízis jellegét emelték ki, amit elsősorban a menekülőket Magyarországon fogadó embertelen körülmények okoztak. A segítők feladata saját értelmezésükben a katasztrófa elkerülését célozta. Ebben olyanok is egyetértettek, akik a menekültek befogadásának hosszabb távú kérdéseivel kapcsolatban eltérő álláspontjuk volt:

El voltunk foglalva általában azzal, hogy mit tudsz, hányan jöttek, hány szendvics kell, tehát teljesen a napi. Megfogalmazódott egyébként, hogy persze tudjuk, hogy nagyon sok feszültséggel, problémával járhat, de mi most arra szövetkeztünk és nekünk az a dolgunk, hogy mi most humanitárius segítséget nyújtsunk. Ez az elsődleges, tűzoltás, és az összes lehetséges többi probléma csak ezután jön. Mert ha ez nem oldjuk meg, akkor azonnal 
konfliktusforrás lesz, mert ő szomjazik, meg éhezik, mi meg borzalmasan érezzük magunkat, hogy hagyjuk, hogy ők szomjazzanak meg éhezzenek. valóban elvitte a maximális energiáinkat az, hogy enni kapjon mindenki, meg elegendő információkat. ${ }^{5}$

A közvetlen kríziskezelésen túl a segítők egy része a menekültek tájékoztatását és eligazítását is feladatának tekintette. Ez együttműködést feltételezett a civilek és az állam között, ami viszont csak ideig-óráig müködött. Voltak, akik nem foglalkoztak vele, vagy egyenesen megtagadták az állami utasítás teljesítését, miszerint a menekülő embereknek minél előbb magyarországi menekülttáborokba kell eljutniuk. Ök azt vallották, hogy a menekülteknek maguknak kell dönteniük saját sorsukról, ahogyan a következő interjúalany is érvel:

Mi meg azt gondoltuk, hogy ezek felnőtt emberek és el tudják dönteni. Itt jövünk mi, hogy segítsük azt, hogy amit döntöttek, azt meg tudják valósítani. Viszonylagos normális fizikai állapotban éljék túl ezt a pár napot. És ebből komoly viták voltak. Azért az érzelmi csúcsokon volt olyan Migration Aid-es aktivista, aki azt mondta a Nyugatiban, hogy azoknak adhatunk kaját, akik felszállnak a buszra. Tehát ilyen típusú viták voltak. Meg hogy a meleg étel osztása az ideszoktatja őket, vagy nem, tehát mi innen voltunk támadva, hogy itt meleg ételt osztunk és ezért nem fognak bemenni a táborokba, mert itt meleg ételt kapnak. ${ }^{6}$

Kutatókhoz hasonlóan interjúalanyaink is érzékelték, hogy 2015 nyara kivételes alkalom volt a magyar civilek és önkéntesség történetében. Egy kifejezetten ellenséges közegben több tízezer ember mobilizálódott, kevés előzetesen létező intézményre, korábbi kapcsolatra és a közösségi média nyújtotta lehetőségekre építve gyorsan és hatékonyan szerveződtek meg. Ennek okaként egyrészt a politikai környezetet, másrészt az alacsony belépési küszöböt, harmadrészt a civilek és az intézményes politika szétválását nevezik meg korábbi kutatások és interjúalanyaink egyaránt. Sokan hangsúlyozták, hogy a menekülteknek nyújtott segítség kivételes alkalom volt arra, hogy megteremtse az önkéntesség értelmét, a civil társadalom erejét Magyarországon.

Szeretnénk azt elérni, hogy Magyarországon civil csoportok megmozgassák azokat az embereket, akik otthon ülnek a plusz egy kiló rizsen, amit ugye ki fognak dobni, vagy megfőznek és ki fogják dobni. Hogy fogják meg és adják oda a szomszédnak, vagy fogják meg és adják le a gyűjtőpontokra és adják oda, hogy mi tudjunk belőle főzni azoknak, akik rászorulnak. $^{7}$

A felelősségvállalás nem a rászorulókkal, hajléktalanokkal, szegényekkel, betegekkel való civil szolidaritás erős magyarországi tradícióival magyarázható, legalábbis távolról sem olyan mértékben mint Németországban, ahol egy különböző területeken aktív civil társadalom csoportosította át az energiáit a menekültek megsegítésére. A magyar civilek és önkéntesek egy része az állam felelötlenségével és az üldözöttek hibáztatásával magyarázza a mozgósítást. A krízis helyzetben levő emberek közvetlen látványa és a szervezett felelőtlenség együtt eredményezték a döntést sokaknál, hogy öneröböl kell ellátni a krízis helyzetből fakadó legsürgősebb feladatokat.

Ez nagyon jól látszott, hogy ebben az országban mi magunkra számíthatunk. Ez az állam, ha egyszer úgy gondolja, hogy mi ne számíthassunk rájuk, akkor nem fogunk tudni ezzel mit csinálni. De hogy ezt az tette plasztikussá, hogy volt ellenálás. Voltak emberek, akik azt

\footnotetext{
5 5. interjú

6 2. interjú

7 31. interjú
} 
mondták, hogy jól van, ti nem adtok WC-t, nem adtok inni, akkor mi ebbe annyit fogunk beletenni, amíg ennek vége nincs. ${ }^{8}$

A segítés kultúrája, az önkéntes munka értéke nem csak kifelé irányuló üzenet, hanem fontos közös tapasztalata volt az együtt dolgozó önkénteseknek. Az önkéntesség irodalma régen ismeri, sokszor erőteljesen kritizálja a segítők jó érzését, a mások segítéséből származó morális vagy érzelmi nyereséget. Mi azonban úgy látjuk, hogy ez az érzelmi nyereség megerősítette a segítőket, hogy helyt tudjanak állni egy olyan környezetben, amely nagy erőkkel deligitimálta a szolidaritást. A közösségélmény különösen erős volt azoknál, akiknél ez kollektív cselekvéssel (közös főzésben, ételosztásban, ápolásban) függött össze.

Az éri meg talán, hogy egy nagyobb valaminek a részévé válsz. (...) De ez így jó volt, hogy tényleg valami fontos dolog, mert most ritkán van ilyenben részem. Hogy valami, amiről tényleg azt gondolom, hogy fontos, és abban több ember együtt tud működni. És annak van valamilyen pozitív élmény karaktere, amit nehéz megtalálni máshol. (...) Ebben van valami spirituális dolog, ami egy plusz regiszter, tehát az nem mosható össze sem a szakmai, sem a családi, sem a magánéleti, hanem ez mellette egy olyan, ami ad valamilyen többletet. Tehát ahhoz kell az, hogy ez ne egy ilyen egyszemélyes akció legyen. ${ }^{9}$

A menekült-segítés közéleti célja néhány interjúalanyunk és a velük kapcsolatban álló civil közösségek számára egyértelmủen elsődleges volt. A civil önkéntesek munkája a magyar kormányétól eltérő politikai álláspont felépítésére szolgált, a szolidaritásról szóló beszédet hitelesítette és terjesztette. Ahogyan az egyik menekülteket segítő közösség alapítója fogalmazott:

Azt meg is fogalmaztuk az elején, hogy nekünk kettős célunk van, hogy operatívan segítsünk a menekülteknek, amiben csak tudunk, a másik az, hogy ezen keresztül, ez részben egy elfecsérelt energia lenne, ha nem használnák ki a sajtót erre, hogy a közbeszédet, a magyar diskurzust formáljuk egy kicsit. ${ }^{10}$

A humanitárius cselekvés egyesek szerint egyenesen politikai tett volt, ami erőteljesen összefüggött a cselekvés politikai okával, azokkal az ellenérzésekkel, amiket az idegenellenes indulatokat manipuláló politikai diskurzusok ébresztettek a megkérdezettekben. Az alább idézett interjúalany vajmi keveset beszél konkrét cselekvésekről, annál többet a biztonság és védelem diskurzusával szemben felépítendő szolidaritás diskurzusáról.

Egy olyan helyzetben, amikor ezrével érkeznek a menekültek, a kormány közpénzből folytat egy gyülöletkeltő kampányt, nem azért, hogy most ezzel megoldódna valami, hanem azért, hogy a népszerűségvesztését visszacsinálja, tehát rövidtávú politikai célok érdekében beláthatatlan következményekkel járó szellemet ereszt ki a palackból, ebben a kérdésben odaállni a menekültek mellé és megetetni, megitatni őket, megsimogatni a fejüket, ez egy politikai állásfoglalás. ${ }^{11}$

Kutatásuk egyik legfontosabb, és ugyanakkor legkevésbé várt eredményét mutattuk be ebben a fejezetben: azt, hogy menekült-segítők felelősségüket csak részben értelmezték az embertelen helyzetben látott emberek vonatkozásában. Ebben a tekintetben az általuk elképzelt legalapvetőbb szükségletek kielégítését tekintették feladatuknak. Másrészt azonban

\footnotetext{
82 interjú

${ }^{9}$ 26. interjú

1015 . interjú

11 15. interjú
} 
felelősségüket a magyar társadalomra és közéletre vonatkoztatták. Vagyis a jótékony cselekvés, miközben nyilvánvalóan, és az interjúkból is igazolható módon a menekült emberekre irányult, elgondolt célja a magyar közvélemény alakítása, a társadalmi szolidaritás kiterjesztése, és az önkéntesség megerősítése volt a magyar társadalomban. Ugyancsak erősen reflektáltak a segítés célja és tárgya vonatkozásában az önkéntes munka érzelmi és morális hatásaira, ami a cselekvésből merít elégtételt és legitimitást olyan értékek fenntartására, mint a szolidaritás vagy a könyörületesség.

\section{A jótékony cselekvés normatív keretezése}

A segítés értelmét ideológiákkal, értékekre való hivatkozással határozzák meg a segítők, amelyek normatív értelemben támasztják alá a cselekedetet. A norma legtöbb esetben úgy válik explicitté, hogy a beszélő annak sérüléséről számol be, továbbá arról a segítő cselekvéshez kapcsolt igyekezetröl, amelynek célja a norma helyreállítsa. Az ideológia és a cselekvés között ennek folytán egy dinamikus viszony alakul ki, egyrészt a norma indokolja a cselekvést, másrészt a cselekvés révén tartható fenn a norma.

Ebben a fejezetben azt tekintjük át, hogy milyen érveket használtak a magyarországi jótékony cselekvők a menekülteknek nyújtott segítség normatív alátámasztására. ${ }^{12}$ Az interjúk elemzése nyolc fajta normatív érvet tudott azonosítani, amelyek az interjús korpuszban való elöfordulás gyakoriságának sorrendjében a következök.

3. Táblázat: A jótékony cselekvés normatív keretei

\begin{tabular}{|c|c|c|c|}
\hline & $\begin{array}{l}\text { Említő } \\
\text { személyek } \\
\text { száma }\end{array}$ & $\begin{array}{l}\text { A szövegkorpuszban való } \\
\text { előfordulás gyakorisága }\end{array}$ & $\begin{array}{l}\text { A szövegkorpuszban való } \\
\text { előfordulás százalékban }\end{array}$ \\
\hline $\begin{array}{l}\text { Univerzális felelősség, morális } \\
\text { érvek }\end{array}$ & 18 & 44 & 29,7 \\
\hline $\begin{array}{l}\text { Politikai felelősség, aktív } \\
\text { állampolgárság }\end{array}$ & 15 & 23 & 15,5 \\
\hline $\begin{array}{l}\text { Privát és korporatív felelősség } \\
\text { erőforrások fölött való } \\
\text { rendelkezés }\end{array}$ & 10 & 15 & 10,1 \\
\hline $\begin{array}{l}\text { Szakmai felelősség (szociális } \\
\text { szakma, tanár) }\end{array}$ & 9 & 24 & 16,2 \\
\hline $\begin{array}{l}\text { Identitás alapú szolidaritás (ők is } \\
\text { migránsok, mint én; } \\
\text { kisebbségben vannak, mint én) }\end{array}$ & 8 & 12 & 8,1 \\
\hline $\begin{array}{l}\text { Nemi és családi szerepekkel } \\
\text { indokolt kötelesség (nőként, } \\
\text { szülőként) }\end{array}$ & 8 & 10 & 6,8 \\
\hline $\begin{array}{l}\text { Történeti reciprocitás (1956, } \\
\text { jugoszláv háború) (“nekünk is } \\
\text { segítettek") }\end{array}$ & 7 & 8 & 5,4 \\
\hline $\begin{array}{l}\text { Keresztény és más vallási morál, } \\
\text { felebaráti szeretet parancs }\end{array}$ & 5 & 12 & 8,1 \\
\hline Összesen & & 148 & 100 \\
\hline
\end{tabular}

\footnotetext{
${ }^{12}$ Ehhez kapcsolódóan egy részletesebb elemzésért lásd Feischmidt 2017
} 
A menekültsegítésnek értelmet adó normatív diskurzusok közül az univerzális, vagyis az egész emberi nemre kiterjedő felelősség (humanitarizmus) volt a leggyakoribb. Eszerint azért kell a menekülteknek segíteni, mert rászoruló emberek, akiken segíteni általános emberi kötelesség. Egy segítő az alábbiakban azokkal szemben érvel, akik segítésre érdemes és érdemtelen kategóriákat hoznak létre:

Vannak szituációk, amikor mindenkinek segíteni kell, másfajta etika múködik, itt nem lehet felmérni, hogy ki érdemes és ki nem. Nagymamám nekem egy dolgot mondott, ha valaki kér segítséget, segíts, ne kérdezd, meg miért kéri, ha kéri, akkor rászorul. És ez működött bennem! Ilyen helyzetben nem lehet és nem is tisztük a segítőknek megítélni, $\mathrm{h}$ ki érdemes és ki nem. ${ }^{13}$

A humanitárius segítség ugyan nem személyválogató, de helyzetekhez kötött, azokhoz a rendkívüli vagy krízis helyzetekhez, amelyeket a mobilizált emberek humanitárius katasztrófaként érzékelnek. A rendkívüli helyzet, ahogyan arra Agamben (1995) figyelmeztet, a szenvedő emberre irányítja a figyelmet, akihez való adekvát viszonyulás a jótékonyság (charity). A szenvedés által kiváltott gondoskodás ezért depolitizál; mégpedig azáltal, hogy eltereli a figyelmet a szenvedés okáról, és ráirányítja a megmentésre vagy a szenvedés enyhítésére.

A humanitárius ideológiához hasonlóan - ez alá sok esetben betagozódva - a szenvedők közti különbségtevés visszautasításán alapulnak a professzionális segítségnyújtás tanárok, orvosok, szociális munkások, önkéntesek által osztott elképzelésrendszerei. A szükséget szenvedö, kiszolgáltatott másokért való szakmai alapú felelősségvállalás ugyanakkor a humanitáriussal szemben nem egy időből kiragadott állapot, hanem folyamatos az érvényessége, jogossága, értékessége. Ezek olyan diskurzusok, amelyek az állam keretei közt létrejövő kormányzás részei (Foucaultra utalva a pásztori hatalommal írhatóak le), ugyanakkor e helyzetekben az állampolgárság korlátai közül könnyedén átemelhetőek a menekültekkel való találkozás transznacionális tereibe.

Az orvosi szakma ilyen szempontból egyszerű, van egy eskünk, ami arra kötelez minket, hogy bárkinek, aki bajban van, segíteniük kell, illetve a segítés módja is teljesen egyértelmű. Ha fáj, fájdalomcsillapítót adunk, ha be kell küldeni a kórházba, akkor beküldjük a kórházba, vagy bekötözzük a lábát. Baromi egyszerū volt. ${ }^{14}$

Három, az egyházi hierarchiáktól és az államtól távol álló vallási közösség tagjainál és vezetőinél találkoztunk keresztény vallási érveléssel. Miként már az előbbiekben szó volt róla mindkettő szociális alapon, és előző tevékenységeikkel összefüggésben viszonyult a menekültekhez, amit az Új testamentumban megfogalmazott szeretetparancsra való hivatkozással támasztottak alá. Ezek az érvelések gyakran tehát az egyház intézményi keretébe ágyazódó szakmai szolidaritásokat és a vallási etikai elveket kapcsolták össze. A következő részlet az utóbbiakat hangsúlyozza:

Minket is elért ez a dilemma, hogy csinálni, de mit? Hogyan? Hogy kell ehhez a problémához hozzányúlni? Kicsit forró krumpli volt, mindjárt egy nagy társadalmi vita közepén találta magát az ember. (...) Töprengtünk, keresztény emberek vagyunk, imádkoztunk, és akkor az vált világossá, hogy azt kéne tenni, amit szerintünk Krisztus is tenne. Bekötözni a véresre

\footnotetext{
1325 . interjú

${ }^{14} 18$. interjú
} 
gyalogolt lábakat, megitatni a kiszáradás közelében lévő kisgyerekeket, adni takarót a fázóknak, imádkozni velük, törődni a lelki életükkel. ${ }^{15}$

Szintén a szenvedést állítja fókuszba a menekültek és segítőik társadalmi kirekesztettségének hasonló tapasztalatairól szóló kétféle beszédmód. Az elsőben a történelmi traumák kollektív és személyes emlékezete jelenik meg: a zsidóüldözések és a holokauszt, a kitelepítések valamint a huszadik század második felének magyar társadalmat érintő menekülthullámai, az 56-os magyar menekültek sorsa, a rendszerváltás előtti romániai-, vagy a 90-es évek délszláv háborúit követő menekülthullámok. A második is a sorsközösséget hangsúlyozza: a beszélő kirekesztettségének egyéni tapasztalatán keresztül, az etnikai vagy nemi kisebbségi valamint a migráns pozícióból megtapasztalt elutasítás és hátrányok perspektívájából indokolja a menekültek segítését. Mindkét beszédmódban a hasonlónak tételezett szenvedés a menekülteket kizáró, megbélyegző biztonságosító diskurzus elutasításához vezet, és a segítségnyújtás kötelességének a megfogalmazásához. A következő részletben az interjúalany a kitelepítések családi emlékezetében horgonyozza le a menekülteknek nyújtott segítségét:

Amikor ott átvonultak Budaörsön, a batyujukkal, babakocsit tolva, gyereket az ölben, idős ember, stb. az teljesen olyan volt, mégiscsak egy sváb település, ahol kitelepítettek az emberek, ott állt anyám, a szüleim budaörsiek, és zokogott. Akkor értettem meg, hogy ez micsoda. ${ }^{16}$

Interjúalanyaink gyakran hivatkozták a szükséget szenvedő gyerekek segítésének imperatívuszát is. Részletes leírások, vagy egyszerü utalások formájában; beépülve a korábban említett humanitárius, szakmai vagy keresztényi kötelességek elképzelései közé, vagy önmagában állva mindenképp az egyik legerösebb legitimációs eszköz az önkéntesek számára. Eszköz abban az értelemben is, hogy a menekült gyerekek segítését nem csupán a saját motivációk feltárásaként idézik, hanem olyan stratégiaként, amely a szekuritizációs diskurzussal átitatott helyzeteket is felülírja, a segítési szándékot e helyzetekben is megidézi.

Nem csak beszélni róla, hanem kimenni, ezzel azért nehezen tudnak vitatkozni, hogy te kimész és ott kisgyerekeket, kirakni a Facebookra egy kisgyereket, hogy pont olyan, mint a te kisgyereked és fázik. ${ }^{17}$

A segítség egyik jellemző módja az adományozás volt. Az adományozást vállalat tulajdonosok és vezetők, továbbá magukat biztos középosztályi helyzetben tudó emberek társadalmi és anyagi státuszukkal összefüggő sajátos felelösségükkel indokolják. Ez egy olyan beszédmód, amely az enyhítendő szenvedések mellett a társadalmi struktúrára, azon belül az anyagi-gazdasági pozíciók tágabb rendszerére is reflektál. Ebben a keretben az anyagi stabilitás és az erőforrás-felesleg egy szélesen értelmezett társadalmi reciprocitás és implicit igazságosság jegyében felelősséggel ruházza fel mindazokat, akik a társadalmi struktúra felsőbb pozícióiban vannak. A Helsinki Bizottságot jelentős összeggel támogató vállalat tulajdonos fogalmazta meg a következőket:

Nekem nincs szükségem arra az érzésre, hogy én a saját kezemmel kivigyek egy pokrócot a Keletibe. Iszonyatosan fontos, amit csinálnak, és mint magyar honfitársaimra, nagyon büszke vagyok, hogy ezt csinálták (...) Erre nekem sem időm, sem energiám, és viszolygok a látványos gesztusoktól. Abban a szerencsés helyzetben vagyok, hogy pénzem viszont van, és azt

\footnotetext{
15 17. interjú

16 18. interjú

17 18. interjú
} 
gondolom, hogy akinek van, annak felelőssége is van ezzel kapcsolatban, hogy egy kicsit vissza kell adni. ${ }^{18}$

Az eddigi keretezések közül néhány (a humanitárius és szakmai segítői ideológiák, a keresztény felebaráti szeretet ideológiája, vagy a gyerekek iránti felelősség elképzelései) elsősorban a menekültek szenvedését állították a középpontba; mások (a kirekesztettség kollektív és egyéni tapasztalata) a menekültek és a potenciális segítők hasonló szenvedéseit, sorsközösségét. A segítést alátámasztó második leggyakoribb érv, az állampolgári vagy politikai felelősségtudat, ami mintha a depolitizáló érvelések inverze lenne. A politikai legitimáció elsődlegesen nem a segítettekből indul ki, hanem abból a politikai környezetböl, amely az embertelen körülményeket fokozza és a veszélyeket hangsúlyozó, biztonságpolitikai diskurzust létrehozza. A rossz politikai közérzet és a politikai felelősségtudat által vezérelt jótékony cselekvés közötti kapcsolatot nemcsak a kormánykritika, hanem, és elsősorban, intenzív negatív érzelmek teremtik meg, amelyek közül a leggyakrabban a szégyenről beszélnek a magyarországi segítők:

Gyúlöletkampány volt, és ezt az emberek elhitték, az emberek benn ragadtak a kommunizmusba, amit mond a vezér, azt elhiszik. Ezért szégyellem magam, hogy magyar vagyok, hogy a magyaroknak ilyen vezetésre van szüksége. ${ }^{19}$

Teljesen jogos volt a szégyenérzet. Amely azóta sem kisebb. A kormányzat uszító kampánya, a külön utassága, az alkalmazott „megoldásai”, a többségi társadalom közönye, sőt, inkább gyúlölete mi másra adna okot? ${ }^{20}$

A jótékony cselekedeteket értelmező érvkészlet része a megsértett állampolgári öntudat helyreállítása is, amely összekapcsolódik egy morális érveléssel: a menekülteknek segítő magyarok az erkölcsös és szolidáris - civilizált - Magyarország képét akarták helyreállítani a menekültekhez való brutális viszonyulásról elhíresült képpel szemben. ${ }^{21}$ A mozgósítás sikeressége büszkeséggel tölti el a beszélők többségét. Ez itt a társadalmi szolidaritásra építő nemzeti identitás keretei között fogalmazódik meg, illetve áll helyre.

Ezt abszolút diadalmenetnek érzem. Bebizonyosodott, hogy létezik emberség. A csöndes többség mellettünk volt. Ami azonban rendkívüli, az az, hogy a szolidaritás, a valódi emberbaráti cselekvés utat keresett és talált magának. A segítők megszervezték magukat és a „profik” méla közönye helyett valódi szeretettel fordulnak azok irányába, akik hozzánk érkeznek. Azok a menekültek, akik szerencsések lehettek és az elmúlt hetekben a Köztársaság téren várakoztak és innen indulva hagyták el az országot, ránk magyarokra úgy fognak emlékezni, mint egy segítő és támogató népre, akik ételt vittek az éhezőknek, italt a szomjazóknak, gyógyírt a régóta gennyedző sebekre és tiszta ruhát az elrongyolódott helyett. És talán ez mindennél fontosabb! ${ }^{22}$

Összegzésképpen megállapítjuk, hogy a magyarországi környezetben a menekülteknek nyújtott közvetlen segítséget két körülmény, a krízis helyzet és a biztonságosítás intenzív

\footnotetext{
18 19. interjú

19 9. interjú

${ }^{20} 23$. interjú

${ }^{21}$ Ez a civilizációs küzdelem gyakran egy „nyugati”, nyugat-európai tekintetre hivatkozik, azonosítva a „jóságot” és „,befogadást” a civilizált Nyugattal. Mindeközben eltekint az „Európa-erőd” évtizedes múltra visszatekintő nyugat-európai vitáitól, a szekuritizációs diskurzus múködésétől.

22 30. interjú
} 
politikai retorikája határozta meg leginkább, ezzel összefüggésben értelmezendő két legitimációs ideológia, a humanitarizmus és az állampolgári felelősség meghatározó volta. A további ideológiák, mint a keresztény morál, a hétköznapi vagy szakmai szolidaritás, vagy a gyerekek segítésének imperatívusza többnyire az előbbivel kapcsolódnak össze. A szakirodalomnak azt az állítását, hogy a humanitarizmus depolitizál részben találtuk a magyarországi esetben igazolhatónak. Másfelől viszont azt találtuk, hogy a humanitarizmus és az állampolgári felelősség diskurzusa összekapcsolódik. Ennek a kapcsolódásnak egy specifikus módját mutattuk be: az állampolgári-közéleti irányultságot interjúalanyaink a jótékonyság egyik központi motivációjaként, legitimációs normájaként idézik. A humanitarizmus és az állampolgári felelősség összekapcsolódásának egy másik módját a következő fejezetben mutatjuk be.

\section{A segítő-segített interakciók formatív hatása}

A másokért viselt felelősség civil formáinak müködésében a közvetlen segítségnek meghatározó szerepe van. A gondoskodás értelmezése szempontjából pedig különösen fontos a segítők és segítettek közötti interakciók tapasztalata. A magyarországi menekült segítőkkel készült interjúk azt mutatják, hogy ezekről az eseményekről, a benne résztvevőkről, az interakciók körülményeiről és hatásairól bőségesen és szívesen beszéltek a megkérdezettek. Vagyis a találkozásoknak formatív hatásuk volt annak ellenére, hogy az adott körülmények miatt többnyire rövid ideig tartottak. Több szempontból elemeztük az interakciókról szóló történeteket. Itt most különösen abból a megközelítésböl tárgyaljuk az elemzés eredményeit, hogy a jótékony cselekvésben szerepet játszó segítő-segített interakciók, illetve azok elbeszélése milyen elmozdulást idéztek elő a jótékonyság és a felelősség különböző formáinak értelmezésében.

A leggyakrabban azzal találkoztunk, hogy az interakció által az elbeszélő új ismeretek birtokába jutott, amelyek formatív hatással voltak arra, ahogyan látja egyfelől a menekültek helyzetét, másfelől saját társadalmi és politikai környezetének hozzájuk való viszonyát. Az új ismereteket a személyesség hitelesíti. A személyes tapasztalatokból és felismerésekből a menekült válság alternatív diskurzusa épül fel, amelynek igazságát a politikai diskurzusok igazságaival szembesíti az elbeszélö. Az elbeszélések tétje tehát egyfelől az igazság, amely racionális megismerés révén megközelíthető. A segítő-segített interakciók történeteinek van ugyanakkor egy nem racionális tétje is. Azt találtuk, hogy a segítők érzelmi reakciói jelentik az interakciók keretezésének második leggyakoribb módját. A különböző motivációkból létrejövő segítő cselekvést az elbeszélés csúcspontjaként elmondott érzés (együttérzés, empátia, szégyen, szeretet) teszi hitelessé ebben az esetben. Az interakciókhoz kötött érzelmek, talán még inkább, mint az ismeretek, változást hoznak, vagy változást jeleznek.

A közért viselt felelősség és a jótékony cselekvés közötti elmozdulásnak két formáját fogalmazzák meg az interakciókhoz szorosan kötődő történetek. Az egyik az előzetesen meglévő ideológiákra és értékekre épülő viszonyulások megerősítése a segítő-segített interakciókban, vagyis a bizonyosság a könyörületesség, szolidaritás, együttérzés jogossága felől. A másik diszkurzív stratégia a menekült segítést stigmatizáló domináns beszédmódok leleplezésére és a személyes interakciókban megismert valósággal való szembesítésére szolgál.

\section{Táblázat: Közvetlen tapasztalatok, menekültekkel való interakciók elbeszélései}

\begin{tabular}{|l|l|l|l|}
\hline & $\begin{array}{l}\text { Említő } \\
\text { személyek } \\
\text { száma }\end{array}$ & $\begin{array}{l}\text { A szövegkorpuszban } \\
\text { való elöfordulás } \\
\text { gyakorisága }\end{array}$ & $\begin{array}{l}\text { A szövegkorpuszban } \\
\text { való előfordulás } \\
\text { százalékban }\end{array}$ \\
\hline
\end{tabular}




\begin{tabular}{|l|r|r|r|}
$\begin{array}{l}\text { Segített személyektől származó ismeretek. } \\
\text { Tanuságtételek }\end{array}$ & 17 & 37 & 29,6 \\
\hline $\begin{array}{l}\text { Érzelmi keretezés. A személyes találkozást az } \\
\text { interakció során megélt szánalom, empátia, } \\
\text { düh határozza meg }\end{array}$ & 14 & 29 & 23,2 \\
\hline $\begin{array}{l}\text { Ideológiák, segítő cselekvés értékének } \\
\text { validálása a személyes kapcsolatban }\end{array}$ & 13 & 19 & 15,2 \\
\hline $\begin{array}{l}\text { Közös cselekvés menekült emberekkel (mint } \\
\text { aktív ágensekkel) }\end{array}$ & 12 & 19 & 15,2 \\
\hline $\begin{array}{l}\text { A szekuritizációs politika leleplezése a } \\
\text { személyes interakciók révén }\end{array}$ & 10 & 12 & 9,6 \\
\hline $\begin{array}{l}\text { Strukturális reflexiók a segítő-segített } \\
\text { viszonyra }\end{array}$ & 7 & 9 & 7,2 \\
\hline Összesen & & 125 & 100 \\
\hline
\end{tabular}

A segítők egy része kifejezetten a segítettek ellátására koncentrált, és voltak, akik úgy segítettek, hogy nem is kerültek személyes kapcsolatba menekültekkel. Akiknek viszont volt módjuk beszélgetni menekült emberekkel, a személyekhez kötődő új ismeretek megerősítették a segítés jogosságában és azt elutasítókkal való vitákban. A következő egy tipikus történet, amely a személyes kapcsolatra, az abból származó ismeretekre és a kapcsolat társadalmi kontextusára egyaránt reflektál.

Egy afgán fiú sztoriját tudom, Higmatnak hívják, ő azért jött el, mert tanár volt Kabulban és a tálibok irtják a tanárokat. (...) Az Astoriánál találkoztunk, voltak vagy tízen és láttam, hogy a térképet fejjel lefelé tartják, és megkérdeztem, hogy segíthetek-e. Nagyon bizalmatlanul néztek rám. Mondtam, hogy szoktam segíteni a menekülteknek. Nem sokat értettek, de kicsit megenyhültek. Elvittem őket a Keletibe. Nagyon érdekes volt, hogy milyen lenézően néztek ránk az emberek, a magyarok. És akkor összezsúfolódtunk a liftben és egy nő olyan arcot vágott! Mondom magamba, jaj bele ne haljál, hogy 3 percet velük kell töltened! Jó nem volt virágillatuk, de hát istenem! Szóval, Higmatnak a család dobta össze a pénzt, hogy el tudjon jönni, 4000 euró, a tengeren jött át, 40 nap alatt ért ide, az útról nem beszélt. Még politikát is tanult kint Afganisztánban, tehát ő abszolút a demokrácia mellett van. 25 éves, igazi csupa szív srác, az elején nagyon zárkózott volt, de aztán elmondta, hogy van felesége, de nem szívesen mutatott képet, hátha én kapcsolatba vagyok valakivel és feleségét kinn megöljék. Higmatot elöre küldték, $h$ vesse meg a lábát nyugaton és a család utána jön. ${ }^{23}$

A menekült emberek iránti kíváncsiság összekapcsolódott a személyes kapcsolatfelvétel vágyával, amit a következő interjúalanynál a keresztény szeretet parancs is alátámaszt. Míg az előző interjúalany arról beszélt, hogy a hétköznapi xenofóbiával miként szembesült egy afgán ember társaságában, a következő interjúrészlet azt is megmutatja, hogy a személyes ismeretekből és élményekből miként építkezik a szekuritizáció ellendiskurzusa:

És akkor kimentünk és elkezdtük vinni a szendvicseket, a vizet, meg a beszélgetés... tehát nagyon fontos volt az is, hogy beszélgessünk. Mi magunk is kíváncsiak voltunk, hogy hova tartanak, milyen álmokkal, milyen célokkal, de... mint keresztény ember, abban is érintve éreztük magunkat, hogy ez kiderült, hogy ők úgy érzik, hogy ők most a keresztényekhez jöttek, vagy a keresztény világba. Ez egy felelősség, hogy akkor most ezt hogy mutatjuk be, vagy hogyan reagálunk erre. (...) Mindig voltak ezek a visszatérő szlogenek, hogy marcona, katonakorú fiatalemberek. Ezzel nagyon jól lehet ilyen félelmeket gerjeszteni, és nyilván

\footnotetext{
23 9. interjú
} 
vannak, vannak közöttük terroristák is, hát ennyi millió ember között mindenféle csibész megbújik, semmivel sem nagyobb százalékban, mint egy magyarban, de ez csak az én véleményem. És akkor leültünk négy marcona szakállas katonakorú fiatalemberhez, akikkel beszélgettünk, hogy mi volt, és akkor elmondták a családi tragédiájukat, hogy a testvére egy ilyen nyugati cégnek a parkolóját őrizte és jöttek és felakasztották. És akkor fogta annak a gyerekeit és a nőtagokat, csak aztán elszakadtak tőlük, és a barátjával együtt elmenekültek, hogy ezt már nem lehet bírni. Kiderült, hogy komoly traumák állnak mögöttük, és az a lényeg, hogy beszélgettünk, mondtuk, hogy reméljük, hogy tanulni akarnak itt, és egy nagyon beszélgetés alakult ki, és megkérdeztük a végén szokásosan, hogy imádkozhatunk-e velük... És persze, és akkor imádkoztunk velük, és meg is próbáltuk a gyenge angolságunkkal magyarázni, hogy miről is imádkoztunk és a marcona, katona fiatalember elkezdett zokogni. Ez egy nagyon személyes pillanat volt. Mindig ezt mondtam, akárhányszor nekem a marcona katonakorú fiatalt felhozták, mint egy ilyen félelemgerjesztő sztereotípiát, mindig elmeséltem ezt a történetet, hogy igen, találkoztam ilyen marcona fiatalemberekkel. ${ }^{24}$

Mindkét fent idézett elbeszélés tartalmaz érzelmi elemeket. A gondoskodás és a jótékonyság irodalma nagy hangsúlyt fektet az érzelmi motivációkra. Kutatások azt bizonyították, hogy a passzív részvétböl a segítő cselekvésbe való átfordulásban bizonyos érzelmi momentumoknak van meghatározó szerepük. Az érzelmekkel, mint motivációs tényezőkkel már foglalkoztunk ebben az írásban. Ezen a pontos azt szeretnénk hangsúlyozni, hogy az érzelmeknek a segítök és segítettek közötti interakciók percepciójában és elbeszélésében ugyancsak meghatározó szerepük van.

Az interakcióknak egy speciális módja segítők és segítettek közös cselekvése, amihez az utóbbiaknak egy minden más reprezentációs formánál aktívabb megjelenítése rendelődik. Hosszú ideig tartó és stabil viszonyokra épülő segítés esetén felértékelödik a közös cselekvés, és vele együtt felértékelődik a segítettek személye. A magyarországi politikai környezet megakadályozta ilyen stabil kapcsolatok létrejöttét, elemeit és a rá való igényt azonban ott találtuk abban a keretezésben, amely a cselekvések kölcsönösségét hangsúlyozza. A következő történetet elbeszélő apa, egy jótékony munkát más csoportok felé is hosszú ideje végző ember, egy gyerekével kapcsolatos élményt mesél el az elismerést feltételező keretben.

Amikor láttam a II. János Pál pápa téren a családokat gyerekekkel, akkor azt gondoltam, hogy ezt a saját gyerekeimnek is meg kell mutatnom. A közösségből egy páran, de tényleg csak egy páran, összepakoltunk, részben vásároltunk, játékokat, a kisfiamnak három labdája volt, mondtam, hogy hozd el a labdádat, hátha lesz ott kivel játszani, sőt, oda is adhatnád az egyiket, mert azoknak a gyerekeknek egy sincs, neked meg három van. (...) Egy afgán családnál kötöttünk ki, akikkel volt két kisfiú, ők rögtön értették, hogy miről van szó, rögtön elkezdtek játszani egymással. Azóta is meséli a Márk, az volt az egyik élménye, hogy elvitte a labdát és a kisfiú nem akarta elfogadni, aztán mégis elfogadta, és nagyon örült neki, megköszönte, a másik pedig, hogy átrepült a labda egy virágágyáson és az egyik afgán kisfiú nem átgázolt az ágyáson, hanem megkerülte, úgy hozta vissza. Ezt aztán sokáig mesélte, hogy milyen kulturált volt ez a kisfiú. Érezte ő is a különbséget a propaganda, a minden letaposó, mindenen átgázoló menekültek képe és a kisfiú között. ${ }^{25}$

Sok esetben nincsen interakció, vagy az elbeszélő nem világít rá a segítő helyzetek részleteire, csak azt tudjuk meg, hogy a menekültekkel való közvetlen kapcsolatban megtörténik egy percepció váltás. Az alábbi példák a kontaktus hipotézis legegyszerübb illusztrációi is

\footnotetext{
24 14. interjú

${ }^{25} 16$. interjú
} 
lehetnének. Az első esetben az elbeszélés középpontjában az a normatív ideológia áll, amely a cselekvést megelőzte és a konkrét helyzetből megerösítést, bizonyosságot merít. A második esetben a személyes motivációból vagy hétköznapi szolidaritásból származó cselekvés olyan felismerésekhez vezet, amely a közéleti diskurzusokba is bevonja az elbeszélőt, tapasztalatait a politikai diskurzus leleplezésére használja.

Hogy mi volt a drive? Szerintem olyan mértékben dehumanizálták őket, hogy aki nem akarta ezt az egész dumát bevenni, aki érezte, hogy sántít ez valahol, az meg akart győződni róla, hogy most hogy van. K. Edit mesélte, hogy a nyolcvan éves nagybátyja, aki egy nagyon durva szélsőjobber volt, és ebben az ügyben különösen sokáig elfogadta a kereteket, egy ponton azt érezte, hogy ez nem stimmel. Fogta és feljött, egy órát utazott vonaton azért, hogy ő akkor megnézi ezeket az embereket, hogy kik ezek és fordult egy nagyot. ${ }^{26}$

Közvetlen haszna volt ennek az önkéntes szolgálatnak, hogy azok, akik személyes kapcsolatba kerültek ezekkel az emberekkel, utána már sokkal árnyaltabban látták a képet és sokkal kevésbé reagáltak a médiában (...), facebookon terjedő mindenféle uszító, hergelö, szánakozó, de mindenképpen valamelyik irányban mesterségesen fokozott, hangulatkeltő elemekkel dúsított beszámolókra, fröcsögő vagy csöpögő közléseknek. (...) Látták, hogy nem kell ezt misztifikálni. ${ }^{27}$

Összegzésképpen megállapítjuk, hogy a segítő - segített interakcióknak a jótékonyság megértése szempontjából még akkor is nagyon fontos szerepük van, amikor a tényleges kapcsolat rövid ideig áll fenn segítők és segítettek között. Jelentőségük elsősorban abban áll, hogy elbeszélhetővé teszik az emóciókat és az új felismeréseket. Végső soron a diskurzusok és a felelősségek különböző formái közötti diszkrepanciák felismeréséhez és kezeléséhez, a jótékonyság és a politika közötti viszony dinamizálásához járulnak hozzá.

\section{A segítésről való beszéd keretezései}

A segítés és politika viszonyát érintő három kiválasztott szempontrendszer leíró bemutatásán túl arra is kíváncsiak voltunk, hogy az önkéntesek a segítségnyújtásról és a politikáról alkotott értelmezéseiket milyen alakzatokban kapcsolják össze. E célból a három szempont - a jótékony cselekvés célja és tárgya, a normatív keret, valamint az interakciók elbeszélése együttes megjelenésének módozatait kvantitatív eszközökkel is elemeztük.

A dolgozat három empirikus fejezetéhez Atlas.Ti szoftverrel előállított kódok (azonos interjúkon belüli) együttes előfordulásának mintázatait faktoranalízissel vizsgáltuk, SPSS statisztikai programmal. ${ }^{28} \mathrm{~A}$ faktoranalízis három látens változót segített azonosítani, amelyek a szolidaritás/gondoskodás és politika viszonyának három erős konfigurációját rajzolják körül.

5. Táblázat: A segítés keretezései: rotált faktorsúlyok

\begin{tabular}{|l|c|c|c|}
\hline & $\begin{array}{c}\text { 1. Fakt } \\
\text { or }\end{array}$ & $\begin{array}{c}2 \text {. Fakt } \\
\text { or }\end{array}$ & $\begin{array}{c}\text { 3. Fakt } \\
\text { or }\end{array}$ \\
\hline Menekültekre irányuló: humanitárius katasztrófa & 0,673 & 0,355 & 0,07 \\
\hline
\end{tabular}

\footnotetext{
26 1. interjú

27 31. interjú

${ }^{28}$ Köszönjük Papp Z Attila fontos segítségét, amit e kérdés módszertani kidolgozásához nyújtott.
} 


\begin{tabular}{|c|c|c|c|}
\hline hárítása & & & \\
\hline Segítőkre irányuló: érzelmi vagy morális nyereség & 0,464 & 0,391 & 0,165 \\
\hline $\begin{array}{l}\text { Pártpolitikai aktorokra irányuló: ellenzéki magatartás, } \\
\text { lázadás }\end{array}$ & 0,241 & 0,063 & 0,601 \\
\hline $\begin{array}{l}\text { A magyar lakosságra irányuló: az önkéntesség } \\
\text { megerősítése a magyar társadalomban }\end{array}$ & 0,756 & 0,125 & 0,283 \\
\hline Univerzális felelősség, morális érvek & 0,044 & 0,794 & $-0,064$ \\
\hline Politikai felelősség, aktív állampolgárság & 0,066 & 0,178 & 0,981 \\
\hline $\begin{array}{l}\text { Történeti reciprocitás (1956, jugoszláv háború) ("nekünk is } \\
\text { segítettek") }\end{array}$ & $-0,123$ & 0,819 & 0,281 \\
\hline $\begin{array}{l}\text { Identitás alapú szolidaritás (ők is migránsok, mint én; } \\
\text { kisebbségben vannak, mint én) }\end{array}$ & 0,093 & 0,548 & 0,058 \\
\hline $\begin{array}{l}\text { Ideológiák, segítő cselekvés értékének validálása a } \\
\text { személyes kapcsolatban }\end{array}$ & 0,548 & $-0,094$ & 0,37 \\
\hline $\begin{array}{l}\text { A szekuritizációs politika leleplezése a személyes } \\
\text { interakciók révén }\end{array}$ & 0,843 & $-0,251$ & $-0,046$ \\
\hline Variancia, \% & $23.4 \%$ & $20 \%$ & $16.6 \%$ \\
\hline
\end{tabular}

A kódok együttjárása alapján azonosított narratív keretek első típusát három, a jótékony cselekvés céljára és tárgyára vonatkozó narratíva határozza meg leginkább, a humanitárius katasztrófa elhárítása, a segítőkre irányuló érzelmi és morális nyereség, valamint az önkéntesség megerösítése a magyar társadalomban. Mi több azt látjuk, hogy ezek nagyon szorosan összekapcsolódnak. A segítés tapasztalata mindeközben a közéletre is ráirányítja a cselekvők figyelmét: a személyes interakciók elbeszélésében központi szerepű a szekuritizációs politika leleplezése. Ebben a beszédmódban véljük tetten érni a jótékonyság politizálódását, vagyis azt, ahogy a segítésre és szenvedésre irányuló cselekvések a közéletre vonatkozó új tudások, kritika születéséhez vezetnek.

A második keretezést az univerzális felelősséget feltételező morális érvek és a történeti reciprocitás határozzák meg, a segítők és segítettek relációjának értelmezésében az azonosságnak (identitás alapú szolidaritás) és univerzális szerepeknek van fontos szerepük, a cselekvő-elbeszélő felelősségét ebből származtatja. A segítő-segített személyes relációknak van hatása, de nem annyira jelentős, hogy elmozdulást eredményezzen a közélet irányába. A humanizmus univerzális erkölcsi normája e beszédmódban tehát eltekint a társadalmi-politikai viszonyok reflexiójától, maga után vonja a gondoskodás, ill. jótékony cselekvés depolitizálódását.

A harmadik keretezés legerősebb jellemzője a jótékony cselekvés céljára és tárgyára vonatkozóan a magyarországi pártpolitikai aktorokra való irányultság (némelykor utalásokkal nemzetközi aktorokra is), vagyis a szekuritizációs diskurzussal szembeni fellépés vagy lázadás. A cselekvést legitimáló ideológiák tekintetében pedig a politikai felelösség és állampolgári öntudat a legfontosabb. E beszédmód formatív jellemzője tehát a politikai szándék és a politikai legitimáció. Ennek okán ebben a típusban a közéleti felelősséget látjuk a menekültekkel kapcsolatos jótékonyságban megjelenni.

\section{Összegzés}

Ebben a tanulmányban a jótékonyság és politika kapcsolatát vizsgáltuk a 2015 nyarán Magyarországra érkező menekülteket segítő humanitárius segítségnyújtás önkénteseinek a 
körében. A humanitarizmus kritikai irodalma valamint a társadalmi mozgalomkutatás hangsúlyozza, hogy az együttérzés és sajnálat által dominált segítségnyújtás a szenvedés és hiányok strukturális okairól elvonja a figyelmet, a megoldás felelősségét pedig az államok helyett az egyéni aktorokra terheli. Ebben az írásban e létező tendenciák mellett másfajta jelenségeket is találtunk. Bemutattuk, hogy a másokért érzett közvetlen felelősség szorosan összekapcsolódhat a kollektív felelösségtudattal, a demokratikus részvétel müködésével meghatározott nyilvánosságokban és viszonyrendszerekben.

A menekülteket segítő magyarországi önkéntesek értelmezéseit vizsgálva azt találtuk, hogy a politikai cselekvés és a szenvedők önkéntes segítése között egy kétirányú kapcsolat áll fenn. Boltanski és Eliasoph modelljeivel összhangban a mások szenvedésének érzékelése, és rá adott közvetlen gyakorlati válaszok - a segítés - sok esetben elvezet a politikai aktorok felelősségének felismeréséhez, a politikai kritikához. Ezt neveztük a jótékonyság politizálódásának. Egy ezzel ellentétes irányú folyamatban a politikai aktorokhoz - főként a kormányzathoz - való kritikai viszonyulás, és a szekuritizációs beszédmód elutasítása vonja be a jótékonyságba az egyéneket. A jótékonyság a lázadás eszközévé válik, a politikai aktorok ellenében a nyilvános felelősségvállalás egy alternatív módját mutatja fel. Ezt neveztük fentebb a politika jótékonyságba való fordulásának.

E kétirányú dinamikát kvalitatív interjúk segítségével igyekeztünk megragadni. Az interjúkban talált beszédmódok egyike kifejezetten a segítés közéleti motivációit hangsúlyozta: az állampolgári kötelességek és öntudat ideológiájába ágyazva a szekuritizáció nyilvános elutasítását és a kormánykritikát jelölte meg az önkéntesség motivációjaként. Ez a beszédmód nem csupán annak bizonyítéka, hogy a szenvedést enyhítő cselekedetek és az (elsősorban magyarországi politikai mezőről szóló) közéleti gondolkodás jól megférnek egymás mellett, hanem az egyéni reflexiók szintjén e kapcsolódás egyik fő irányát, a közélet felől a segítő cselekvések, a jótékonyság és önkéntes segít nyújtás irányába való elmozdulást is tuikrözik. Az önkénteskedés politikát és segítést összekapcsoló másik elbeszélési módja a segítő gyakorlatokban, a segítő-segített találkozások közben születő érzelmeket és új tudásokat hangsúlyozza. Köztük azokat a felismeréseket, amelyek a szekuritizációs politika leleplezéséhez, és az ezt képviselő politikai szereplők kritikájához vezettek. Ez a beszédmód e két általunk vizsgált szférát, a szenvedés enyhítésének szándékát és a felelősségekről és a nyilvánosság müködéséről szóló politikai véleményalkotást úgy füzi össze, hogy az előbbi felől az utóbbi felé tartó elmozdulást mutatja be.

Az interjúkból kirajzolódó három domináns beszédmód közül a harmadik kifejezetten ügyorientált, ami a segítő cselekvést, a segítők és segítettek interakcióit állítja a középpontba, és igyekszik az értelmezést, a motivációkról való beszédet a közéleti kontextustól, a politikai nyilvánosság müködésének és a közéleti aktorok felelősségének kérdésétől minél távolabb tartani. Fontos ugyanakkor hangsúlyozni, hogy alig néhány válaszoló akadt, aki a segítés értelmezését e depolitizált beszédmódra, a segítők rászorultságára, valamint a segítő-segített relációra korlátozta. A legtöbb válaszoló esetében a két másik beszédmód is hangsúlyosan megjelent, amely tehát a segítő cselekvéseket és a magyarországi közéletre, a nyilvánosságra és a politikai aktorokra vonatkozó véleményeket szorosan összefüzte egymással.

A politika és a szenvedések csökkentésének e kétirányú kapcsolata jelentős részben egy specifikus társadalmi-politikai helyzet, a biztonságosítás hegemóniája születésének a következménye. A hegemónia kontextusában a menekült szolidaritás politikai motivációit továbbá a cselekvés utólagos politizálódását azonosították mások is Európában. Vandervoordt és Verschaegen (2017) a menekültek Belgiumban szervezett önkéntes segítését szubverzív 
humanitarizmusnak nevezte el. Az önkéntes szerveződések politikai karakterét társadalomalakító igényét és erejét - ők is abban látják, hogy a felelősségvállalás ideológiája szembehelyezkedik a biztonságosítás domináns diskurzusával. Magyarországon ennek jelentőségét még inkább növeli a részvételi demokrácia általános válsága, amelyben a részvétel ideig óráig fennálló informális intézményekben valósul meg. A szolidaritási és jótékonysági akciók vizsgálata ebben a tekintetben megerősíti tehát azt a következtést, amelyre Szabó Andrea és kutató társai jutottak politikai részvétel nem intézményi formáinak kutatása során (Oross - Szabó 2014, Oross-Róna-Szabó 2017), a szolidaritást akciói is többnyire elszigeteltek maradnak, nem tudnak stabil intézményeket és ellendiskurzust létrehozni.

\section{Hivatkozások}

Agamben,Giorgio (1995) Homo Sacer: Suveran Power and Bare Life. Stanford University Press

Ágh Attila (2016): Vitairat a "civilek hatalmáról": a védekező társadalom avagy a civilek hatalma: töprengések a magyar civil társadalom helyzetéröl. In: Antal Attila (szerk.): A civilek hatalma. Budapest, Noran Libro.11-46

Anikó Bernát - Anna Kertész - Fruzsina Márta Tóth (2016): Solidarity Reloaded: Volunteer and Civilian Organizations during the Migration Crisis in Hungary. Review of Sociology, Vol. 26., No.4, 29-52. pp.

Bernáth Gábor - Messing Vera (2015): Bedarálva. Menekültekkel kapcsolatos kormányzati kampány és a tőle független megszólalás terepei. Médiakutató, 16. évf., 4. szám, 7-17. o. http://www.mediakutato.hu/cikk/2015_04_tel/01_menekultek_moralis_panik.pdf (utolsó megtekintés: 2016-08-01)

Boltanski, Luc (1999) Distant suffering: Morality, Media and Politics. Cambridge: Cambridge University Press

Butler, Gill: Reflecting on Emotion in Social Work, in Scott, Christine, Scragg Terry (eds.) Reflective Practice in Social Work (Fourth Edition), London: Sage, 2016.

Cantat, C. (2016) Rethinking Mobilities: Solidarity and Migrant Struggles Beyond Narratives of Crisis. Intersections. East European Journal of Society and Politics2, 4, 11-32. https://doi.org/10.17356/ieejsp.v2i4.286

Cantat, Celine - Feischmidt, Margit (2018): Civil involvement in refugee protection: reconfiguring humanitarianism and solidarity in Europe. Margit Feischmidt/Ludger Pries/Celine Cantat (eds.) Refugee Protection and Civil Society in Europe. Megjelenés előtt, Palgrave

Eliasoph, N. (2013) The Politics of Volunteering. Cambridge: Polity Press

Cohen, Jean L. - Arato, Andrew (1992): Civil Society and Political Theory. Cambridge, MIT Press.

Edwards, Michael (2014): Civil Society. Cambridge, Polity Press.

Fassin, Didier (2012): Humanitarian Reason. A Moral History of the Present. Berkeley, Los Angeles, London, University of California Press.

Feischmidt, Margit - Zakariás, Ildikó (2017): Politics of care and compassion. Civic help for refugees and its political implications in Hungary - a mixed method approach. In: Margit Feischmidt/Ludger Pries/Celine Cantat (eds.) Refugee Protection and Civil Society in Europe. (Forthcoming)

Feischmidt, Margit (2017) Szolidaritás és társadalmi reflexió a menekültek önkéntes segítőinek elbeszéléseiben. Socio.hu 2018/1, DOI: 10.18030/socio.hu.2018.1.69

Gerő Márton - Kopper Ákos (2013) Fake and Dishonest: Pathologies of Differentiation of the Civil and the Political Sphere in Hungary. Journal of Civil Society Vol.9, 2013 - Issue 4, 361374. https://doi.org/10.1080/17448689.2013.844449 
Greskovits, Béla 2017 Rebuilding the Hungarian Right through Civil Organization and Contention: The Civic Circles Movement. EUI Working Papers.

Hustinx, Lesley - Cnaan, Ram A. - Handy, Femida (2010): Navigating theories of volunteering: A hybrid map for a complex phenomenon. Journal for the Theory of Social Behaviour, Vol. 40., No. 4., 410-434. pp. [DOI: 10.1111/j.1468-5914.2010.00439.x]

Hustinx, Lesley - Lammertyn, Frans (2003): Collective and Reflexive Styles of Volunteering: A Sociological Modernization Perspective. Voluntas: International Journal of Voluntary and Nonprofit Organizations, Vol. 14., No. 2, June, 167-187. pp.

Kallius, Annastiina - Monterescu, Daniel - Rajaram, Prem Kumar (2016): Immobilizing Mobility: Border ethnography, illiberal democracy, and the politics of the "refugee crisis" in Hungary. American Ethnologist, Vol.43., No.1, 25-37. pp.Karakayali, Serhat - Kleist, Olaf (2016): Volunteers and asylum seekers. In: Forced Migration Review, January, 65-67. pp. Ingram, R.: Understanding emotions in social work: Theory, Practice and Reflection, Berkshire, McGraw Hill, 2015.

Kende Anna (2016): The Politicized Motivations of Volunteers in the Refugee Crisis: Intergroup Helping vs. Political Activism as the Means to Achieve Social Change. Journal of Social and Political Psychology Vol. 5., No. 1. May, 260-281. pp. DOI:

10.5964/jspp.v5i1.642 - License: CC BY 4.0

Kerényi Szabina (2016): Mozgalmi ciklusok és az alulról szerveződő mozgalmak strukturális csapdái. In Antal Attila (szerk.): A civilek hatalma. Budapest, Noran Libro. 85-104

Király Gábor, Dén-Nagy Ildikó, Géring Zsuzsa, Nagy Beáta (2015): Kevert módszertani megközelítések. Elméleti és módszertani alapok. Kultúra és Közösség 4(2) 95-104.

Malkki, Liisa H. (2015): The Need to Help. The Domestic Arts of International

Humanitarianism. Durham and London, Duke University Press.

Menekültek a világban, KSH Statisztikai Tükör, 2016. július 25.

http://www.ksh.hu/docs/hun/xftp/stattukor/menekult15.pdf utolsó letöltés: 2017. 12. 13.

Macrae, Joanna (2002): The new humanitarianisms: a review of trends in global humanitarian action. Report 11, 2002, April. Humanitarian Policy Group, Overseas Development Institute.Melegh Attila (2016): Unequal Exchanges and the Radicalization of Demographic Nationalism in Hungary. Intersections. East European Journal Of Society And Politics, Vol. 2., No. 4, 87-108. pp. doi:10.17356/ieejsp.v2i4.287

Molnár Virág (2016): Civil society, radicalism and the rediscovery of mythic nationalism. Nations and Nationalism, Vol. 22. No. 1, 165-185. pp.

Musick, Marc A., and Wilson, John (2008): Volunteers: A Social Profile. Bloomington, Indiana University Press.

Oross Dániel, Szabó Andrea (2014) A demokratikus részvétel tendenciái a magyar nappali tagozatos hallgatók körében. In Szabó Andrea szer. Racionálisan lázadó hallgatók II. MTA TKPT és Belveder, Budapest, Szeged, 77-98.

Oross Dániel, Róna Dániel, Szabó Andrea (2017) Divergent understandings of politics and motivations for civic participation among the politically active students (Manuscript)

Povrzanović Frykman, Maja és Fanny Mäkelä ( 2017) Refugees Welcome to Malmö. Organisation and politisation of a civil society initiative. In: Margit Feischmidt/Ludger Pries/Celine Cantat (eds.): Refugee Protection and Civil Society in Europe. (Forthcoming) Pries, Ludger (2017): Civil Society and Volunteering in the so-called Refugee Crisis of 2015 - Ambiguities and Structural Tensions. In: Margit Feischmidt/Ludger Pries/Celine Cantat (eds.): Refugee Protection and Civil Society in Europe. (Forthcoming)

Rajaram, Prem Kumar (2016): Whose Migration Crisis? Intersections. East European Journal of Society and Politics, Vol. 2, No. 4. December, 5-10. pp. doi:https://doi.org/10.17356/ieejsp.v2i4.314. 
Simonovits Bori (2016): Mass-Migration Related Fear in Contemporary Hungary: The Social Basis of Realistic and Symbolic Threats. In: The Social Aspects of the 2015 Migration Crisis in Hungary. TÁRKI, 2016. www.tarki.hu/hu/news/2016/kitekint/20160330_refugees.pdf Szalai András - Göbl Gabriella (2015): Securitizing Migration in Contemporary Hungary. Working Paper. CEU Center for EU Enlargement Studies.

Sik Endre (2016): The Socio-Demographic Basis of Xenophobia in Contemporary Hungary In: Bori Simonovits, Anikó Bernát, Blanka Szeitl, Endre Sik, Daniella Boda, Anna Kertész, Fruzsina Márta Tóth, Judit Barta, Bori Simonovits, Anikó Bernát (szerk.)The Social Aspects of the 2015 Migration Crisis in Hungary. Budapest: TÁRKI, 41-47.

Ticktin, Miriam (2011): Casualities of Care. Immigration and the Politics of Humanitarianism in France. Berkley - Los Angeles - London, University of California Press. Vandervoordt, Robin és Gert Verschaegen (2017) Between subversive and professional humanitarianism: on Belgian civil support for refugees. Margit Feischmidt/Ludger Pries/Celine Cantat (eds.): Refugee Protection and Civil Society in Europe. (Forthcoming) Wuthnow, Robert (1991): Acts of Compassion: Caring for Others and Helping Ourselves. Princeton University Press.

Wuthnow, Robert (1995): Learning to Care: Elementary Kindness in an Age of Indifference. New York, Oxford University Press.

Zakariás Ildikó (2016b): Szolidaritás és hatalom a kisebbségi magyarokra irányuló jótékonyságban. PhD Disszertáció. Kéziratban. Budapest, Budapesti Corvinus Egyetem. Zakariás Ildikó (2016a): A menekültek civil segítése: attitűdök és morális érvek. REGIO, 24. évf. 4. sz., 61-87. 